$\frac{396}{3122 T}$

16.2250

MASTER

UCRL-52604

\title{
MEASURING THE PERMEABILITY OF ELEANA ARGILLITE FROM AREA 17, NEVADA TEST SITE, USING THE TRANSIENT METHOD
}

W. Lin

December 11, 1978

Work performed under the auspices of the U.S Department of

Energy by the UCLLL under contract number W-7405-ENG-48

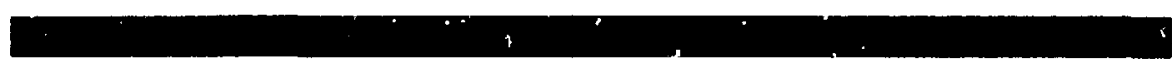

iv
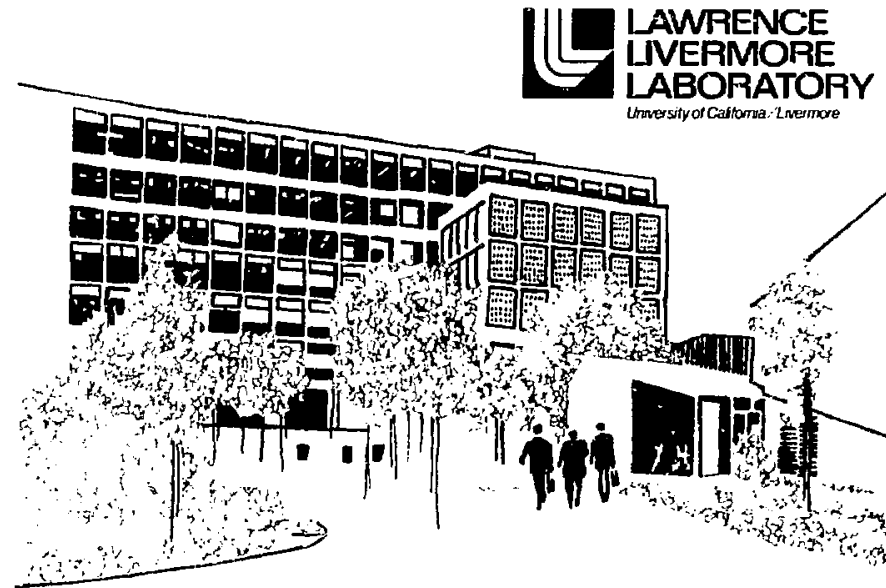

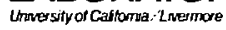

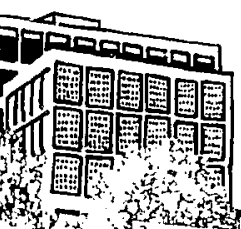

का

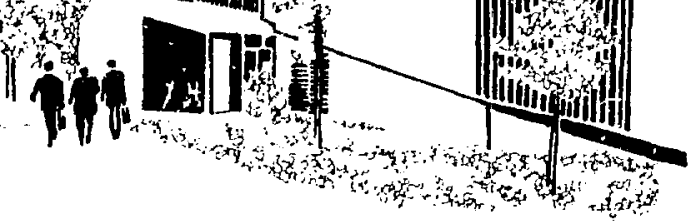




\section{㢟}

LAWRENCE LIVERMORE I_ABORATORY

Unversity ol Caltornia Livermore.Calitornia 94550

UCRL -52604

\section{MEASURING THE PERMEABILITY OF ELEANA ARGILLITE FROM AREA 17, NEVADA TEST SITE, USING THE TRANSIENT METHOD}

W. Lin

MS. date: December 11, 1978 


\section{CONTENTS}

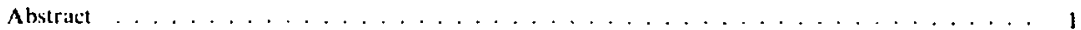

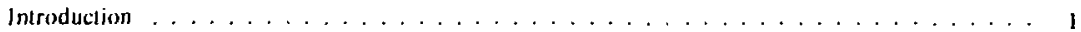

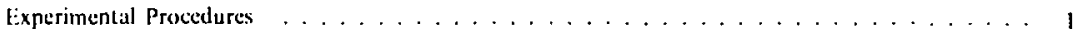

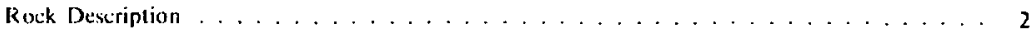

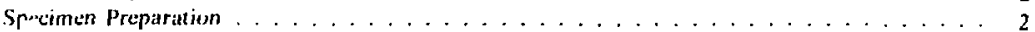

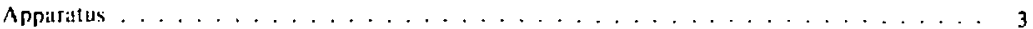

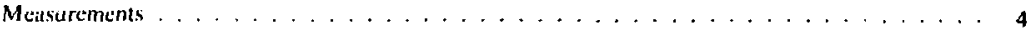

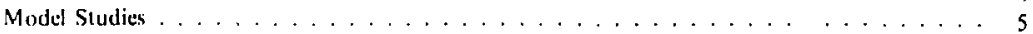

Experimental Uncertainties . . . . . . . . . . . . . . . . . . . . . . . 5

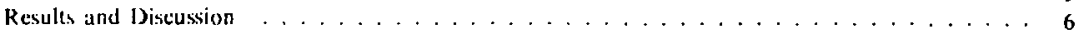

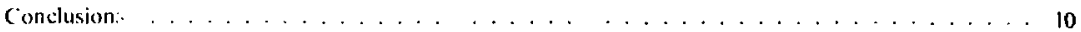

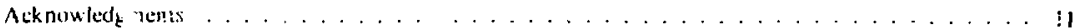

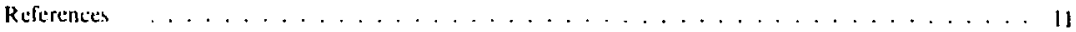




\section{MEASURING THE PERMEABILITY OF ELEANA ARGILLITE FROM AREA 17, NEVADA TEST SITE, USING THE TRANSIENT METHOD}

\section{ABSTRACT}

Using the transient method, we determine the permeability of high-quartz Eleana argillite from the Nevada Test Site as a function of effective pressure. By comparing calculated and observed pressure decay in the upstrear: reservoir, we halve determined the permeability of intact and fractured specimens at effestive pressures ranging from 1.0 to 24.0 MPa. Over this pressure range, Eleanal argillite has a low permeability $\left(10^{-16}\right.$ to $10^{-19}$ $\left.\mathrm{cm}^{2}\right)$ when intact and a higher permeability $\left(10^{-12} 10^{-17} \mathrm{~cm}^{2}\right)$ with one induced through-going fracture.

\section{INTRODUCTION}

When choosing a geological fornation in which to permanently isolate nuclear wastes, one of our major concerns is transportation of radioactive materials to the biosphere by ground water. Therefore, the water permeability of in will rock becomes a major criterion in the selection process. Whice the storage facility is being designed, it is necessary to have laboralory measurements of the water permeability of repository rosks as a function of stresi, pressurs, and temperature. During construction, while the repository is operating, and after it is eloned, these data are needed for properly monitoring the repository's behavior.

The primary goal of the Terminal Waste Storage Program at the Nevada Test Site (NTS) is 10 evaluate the major geological formations with respect is suitability ats locations for permanent storage of high-level radionctive wastes. NTS has a deep water lable with long now paths that eventually discharge into hydrologically closed basins, and there are a number of geological formations that might be suitable for radioalclive waste storage. We cxamined one such site, an argillite (sometimes loosely (ermed "shale") in the Syncline Ridge block of the Fleana Formation. 1

We measured the waler permeibility of intact and fractured specimens of high-quarts Eleana argillice as a function of effective pressure over a range of 1.0 to $24.0 \mathrm{MPi}$. Erfective pressure is the confining pressure minus the pore pressure: we maintained the pore pressure at $50 \%$ of the confining pressure. This is a reasonahle pore pressure to conirning pressure rutio in a normal crustal condition.?

Altbough permeabilities from $10^{-13}$ to $10^{-7}$ $\mathrm{cm}^{2}\left(10^{-5}\right.$ to $10^{\prime}$ d) can be determined by steady. sate metbods, it is better to determine permeabilities less than $10^{-12} \mathrm{~cm}^{2}$ by transient methods. Brace el al. " were the first to use the transient method to deternsine the permeability of Westerly granite as a function of pressure. Brace's simplified method works orly if the pore volume is very smill compared with the total volume of specimen and reservoir, and the bulk compressibility of rock is much simaller than the product of rock porosity and the compressibility of water. We used a more gentral approach, ${ }^{4}$ the details of which are explained in the next section.

\section{EXPERIMENTAL PROCEDURES}

When the specimen (Fig. I) is under a confining pressure, $P_{\&}$, we suturate the specinen and bring it and the connected reservoirs to equilibrium at a port pressure, $P_{p}$. Pore pressure is maintained at 


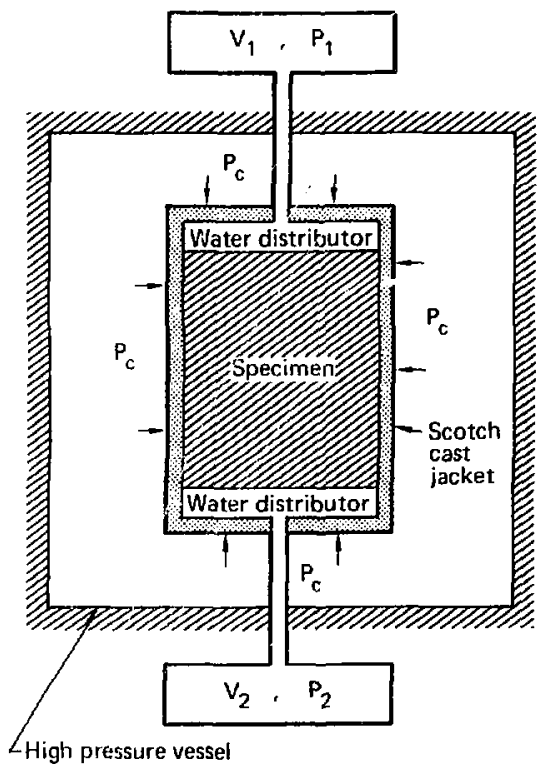

FIfi. I. Schematic diar,ram of the permeshility me'usurement apparatus. $V_{1}$ and $v_{2}$ are the volumes of upsiream and downstream reservoirs, respectively. $P_{1}$ and $P_{2}$ arc the pressures in these reservoirs, $P_{c}$ is the confining pressure.

half the confining pressure (Fig. 1). A small pressure increment, $\Delta P$, is introduced in the upstream reservoir. The pressure decay in the upstream reservoir is then measured. Using a previously published modet ${ }^{4}$ that shows the relation hetween pressure decus and permeability, we determine the permeability of our specimens. Our specimens, apparalus, meisurements, and calculations are expluined in delail in the following subsectious.

\section{ROCK DESCRIPTION}

The Eleana argillite cores are from the UEI7. drill hole in the upper part of Unit $J$ of the Eleana Formation, NTS, at Nevada State Coordinates N.260,057 (853,205) and E.197,037 $(646,4481$. The hole, drilled by the U.S. Geological Survey, was
914.4 m deep. Our specimens are obtitined from the massive. more or less uniform. argillite at deptes greatter than $7.3 .5 \mathrm{~m}$.

The argillite is entirels dark gras to hlack. Knile-hade penetrattion and electrical resistivity less than $20 \Omega \cdot m$ indicitle a clay content of trom 50 (1) 90\%. I The major minerals are quarts. illite, chlurite. katolinite. Pzrophyllite. and siderite Quart content allects the mechanical propertits of the core: high-quart/ argillite $\{\mathrm{s}-\mathrm{rat}\}$ studies show that the quirls concent is 25-40\%) is halrd and trong alfer drying natturally. I.ow-yuarts arg̣illite (less than 25"; quarte) dessicates and sracks when dry. If waler is added alter drying. the rock hecomes soft and lialls apart.

Bedding planes are often obseure in the lower par? of the argillite unit: dips range from 9 to $45^{\circ}$ in the interval from $73.5 \mathrm{lo} 230 \mathrm{~m}$. Dips are 30 to $80^{\prime 2}$ at greater depths. The cotal porosity of arpillite ranges from 6.8 10 $13.5 \%$.

\section{SPECIMEN PREPARATION}

At the drill site, core material was carefully wrapped in aluminum loil and sealed with wax to prevent the loss-or gain-of water during storage. Cjlindrical specimens, $2.54 \mathrm{~cm}$ in diameler and $3.81 \mathrm{~cm}$ long. wer: ijrilled from the drill-bole core. either parallel or perpendicular to the sore atxis. In the spectimens that we studied. the hedding planes dip ihoul 30 to $60^{\circ}$ with respect to the specimen axis. The spetimen ends were ground flat and parallel to each other. within $0.05 \mathrm{~mm}$, across the diameter.

Thete sere two types of specimen geometry. The first was an intalet eylinder, with no visible laults or fractures. The second was identical to the first, except for one induced through-going fracture parallel to the specimen axis. We used the Braril test (diametral loading along the cylindrical surface) to introduce a longitudinal, through-going. tensile frature in specimzens of the second geometry type. In all casts, prepared specimens were kept in a hell jar over water to prevent drying. All permeabilities were deltermined along the axtial direction of the specimen.

Table I lists the specinens, their depths of origin, and their characteristics. We noticed that the specimens from theper rock were denser and harder than the shallower ones. We tried to prepare the low-quartz argillite specimen by coring ether with 


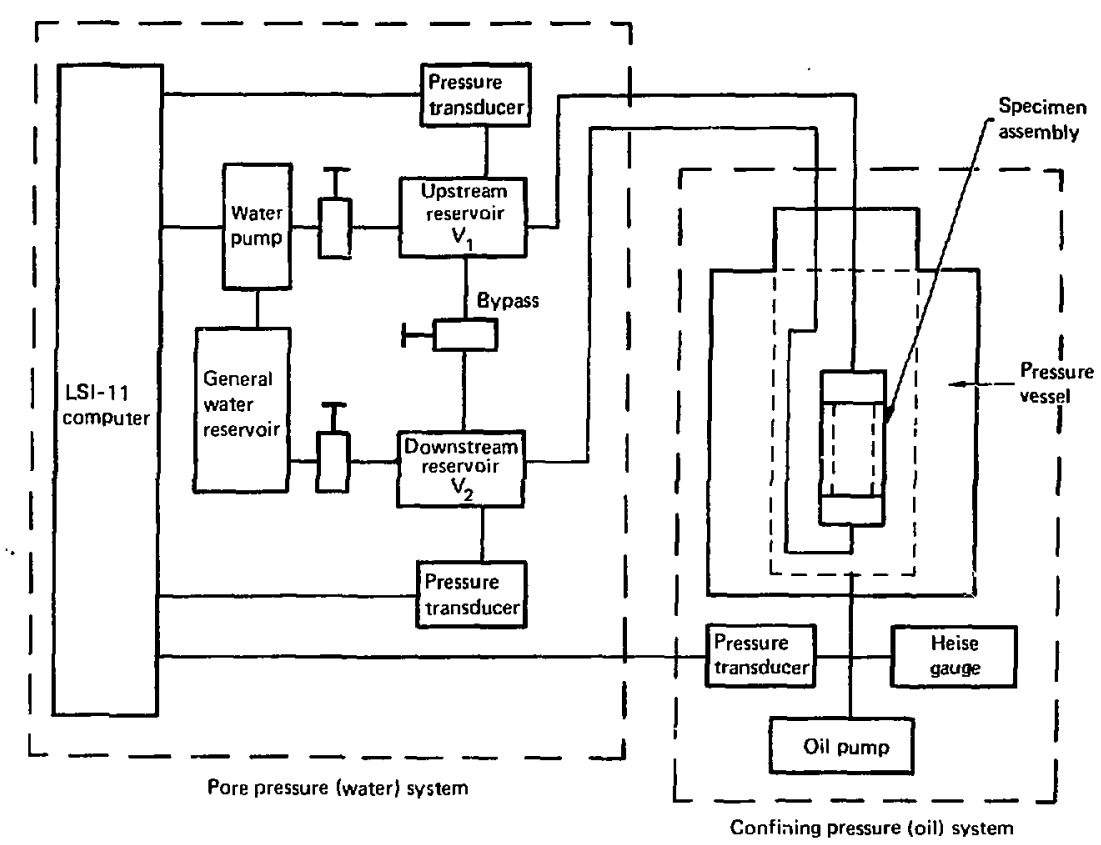

FIG. 2. Simplified diagram showing the connections among the three main parts of the permeability apparatus: specimen assembly, confining pressure system, and pore pressure system.

TABLE 1. Orientation, condition, and depth of origin of test specimens. ${ }^{\mathrm{a}}$

\begin{tabular}{ccll}
$\begin{array}{c}\text { Specimen } \\
\text { No. }\end{array}$ & $\begin{array}{c}\text { Depth, } \\
\mathrm{m}\end{array}$ & $\begin{array}{c}\text { Test } \\
\text { conditions }\end{array}$ & $\begin{array}{c}\text { Orientation with } \\
\text { respect to core axis }\end{array}$ \\
\hline 1 & 102.1 & Intact & Parallel \\
2 & 102.1 & intact & Perpendicular \\
3 & 102.1 & Fractured & Perpendiculas \\
4 & 358.4 & Intuct & Perpendicular \\
5 & 358.4 & Fractured & Perpendicular \\
6 & 361.2 & Intact & Parallel \\
7 & 361.2 & Fretured & Parallul \\
\hline
\end{tabular}

'Bedding planes of these specimens dip from 30 to $60^{\circ}$ with respect to the speeimen axis. water or air, but the material is too weak for adeyuate prepartition by either of these metheds. Al] specimens in Table 1 are from the high-quarke group.

\section{APPARATUS}

The apparatus used in this study (Fig, 2) contains three main parts: the specimen assembly, the confining pressure system, and the pore pressure system. Heard and I reita have described the pore pressure system.

The specimen assembly is held in a high. pressure vessel sinijiar to those used in previous experiments. ${ }^{6-8}$ Confining pressure is supplied by an air-oil hydraulic pamp and monitored by a Heise gauge. 
The two ends of the specinten assembly are connected to the upstrtam and downstream reservoirs ( $V_{1}$ and $V_{2}$, respectively) by high-pressure sapillary tubing. Water pressuse in the reservoirs is supplied by an air-water hydraulic pump, which can be controlled manually or automatically, and measured by transducers. Restrvoir pressure can be recorded manually or automatically by a LS1-11 microcomputer.

The specimen assembly, shown in detail in Fig. 3 , is also sinilar to that used by Lakner." The specimen is jacketed betueen two porous steel plates, which distrihute water evenly over the specimen ends. The sleel caps adjacent to the steel plates conned to the high pressure lines and the reservoirs. The entite unit is encased in Scotch Cast electrical resin 221. which prevents oil from penetrating the specimen. The casting resin is weak enough, however, to transmit hydrostatic pressure. Before casting, we clean the specimen surface and sind the surfites of the steel end caps to ensure complete bonding of the Scolch Cast. The specimen assemhly and high-pressure tubing are then conneeted to the high-pressure vessel plug.

\section{MEASUREMENTS}

Before measuring, we salurate the specimen with water and hring the pore pressure to half the desired confining pressure. Initially, confining pressure is the lithostalic pressure at the samples

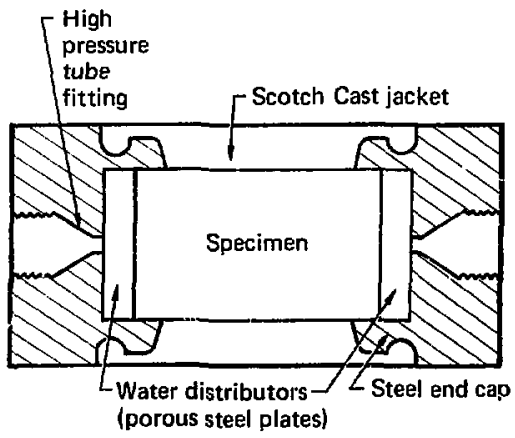

FIC. 3. The specimen assembly encases the specimen between porous steel plates, which act as water distributors. original depth To ensure that the specinen is fully saturatted, we increase confining pressure step by slep and keep the slfective pressurs as small as possible until the desired pore pressure is reached. During saturation, the bypass (Fig. 2) is open so that water can flow into the specinen from both ends. When the reservoir pressure does not vary more than the amount expected from thermal fluctuation for $24 \mathrm{hr}$, we alssume that the specimen is saturated. After the restrvoirs and specimen are equilibrated to the same pressure. He close the bypass and record the presisure thange in tach reservoir for one to two hours.

After ealibration. we increast the pressure in upstrean reservoir $\left(V_{1}\right)$ slightly and record the pressure variation as a function of time. This pressure inerement. from $0.2102 .0 \mathrm{MP}$ il, is usually inuch less than the pore pressure and dees not noticeahly affect the specimen pernicability. Figure 4 shows one example of the shserved pressure-time curve in the upstream reservior after the pressure increment is introduced. The pressure hats been normalized to a full seale ol $2.0 \mathrm{MP}$ P. Note that at the end of the ruts. the pressure increises with time: this is dete to a slight increase in room temperature. The high-frequency lluctuation shoun in Fig. 4 is the clectrical noise from the system. particularly the pressure transducer.

With ather parameters constiont, the smaller the reservoir volune, the faster the presisure decays. Therefore, we used the pair of ::-inall reservoirs (5.95 and $9.25 \mathrm{~cm}^{3}$ ) in all experiments with intict rouk specinens of low permeability. The permeability of fractured specinens is high at low pressure; hence we used pairs of small $\left(5.95\right.$ and $\left.9.25 \mathrm{~cm}^{3}\right)$ and large (545 and $546 \mathrm{~cm}^{3}$ ) reservoirs to double-check our measurements. At higiter pressures, when the permeability of the fractured specimens is reduced, we use the imall reservoirs. We helieve that this method closely approximates the cquivalent permeahitity of the fractured specimen. This is because the water flow through a frictured specimen may he quite different than the diffusion process we assumed in this study, especially at low pressure.

To correct pressure for the effects of leaks or temperature variation or both, we lake the following steps: record the pressure variations ats a function of time before and at the end of an experiment: fit straight lines to the pressure variation to obtain aP/at in the corresponding perjods: take the mean of these two partial derivatives; and subirict-or 


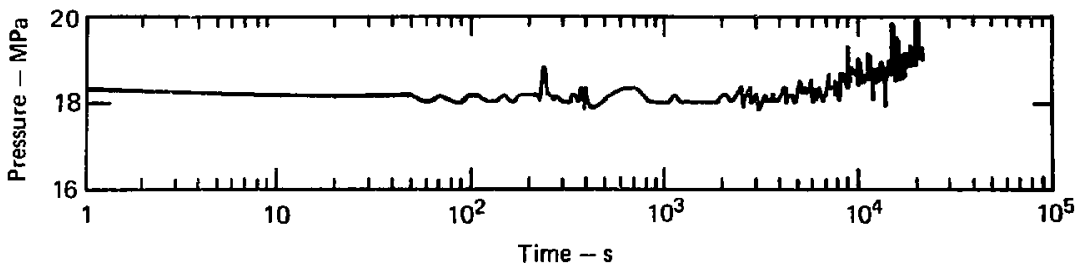

FIG. 4. Observed pressure variations as a function of time in the upstream resenoir. Specimen 1, hith confining pressure $=2.8 \mathrm{MPa}$, pore pressure $=1.6 \mathrm{MPa}$, and pressure increment $=0.15 \mathrm{MPa}$. The pressure is normulized to 2.0-MPa maximum pressure.

add. depending on the sign of $\partial P / \partial t-$ the mean $\partial P$. 2 from the sherved pressure decay eurve. We then compare the average of the observed curves (i.t.. we disregard the electrical nojie) with the culculated curves (riext section, Fig. 5) to determine the specimen's permeability.

The data points in lig. 5 are the corrected obherved pressure viariations in the upstream reservojr. This is the second run of specimen I (Table 1). at $2.8 \mathrm{NPa}$ conlining pressure and $1.6 \mathrm{MPa}$ pore pressure. The permeability from this comparison is $1.5102 .0 \times 10^{-17} \mathrm{~cm}^{2}$.

\section{MODEL STUDIES}

As described above, we observe presisure decay over lime in the laboratory. To obtain specimen permeability from the decay curve, we need to know the relation between speeimen permeability and pressure decay in the reservoir. For a complete deseription of the model and the calculations, see J.in. " Bricily, the computer code TRUMP' is used 10 calculate ontedimensional fluid flow of water through a model system with the sane dimensions as the real system, but with various permeability valus. The input parameters-permeability, porosits. and compressibility of rock and viscosity and tompressibility of water-are listed in Table 2; Fig. 6 is a sketch of the model configuration. In the silculations. the rock is divided into zones perpendicular to the diretion of fluid flow: the number of cones is increalsed until the calculated results do not change significantly with further zonation.

Figure 5 shows the calculated pressure in the upstream reservoir as a function of time for a pair of restrvoirs with volumes of 5.95 and $9.25 \mathrm{~cm}^{3}$ and permeahilities from $10^{-19}$ to $10^{-12} \mathrm{~cm}^{2}$. We compare these curves with the observed pressure-time curve to lind the specimen's permeability.

\section{EXPERIMENTAL UNCERTAINTIES}

Two main sources account for the uncertainty of permeabilities determined by this method:

- Leaks and room temperature changes which effect gressure variation.

- Uncertainty about the true values of several parameters, particularly compressibility and viscosity of water, bulk compressibility, solid matrix compressibility, and the porosity of the specimen.

The effect of the first source is difficult to estimate. However, we helieve that after the corrections shown in the last section, this factor makes our permeability in error by no more than $10 \%$.

The compressibility and viseosity of water and the bulk compressibility of rock are the important factors in our second soures of uncerlainty. The porosity and the matrix eompressibility of rock specimens, in this case, do not play important roles. A $5 \%$ decrease in the assumed compressibility of water (e.g. from 4.2 to $4.0 \times \mathrm{jO}^{-4} \mathrm{MPa}^{-1}$ ) will shift the calculated curce $15 r^{r}$ low ard the higher permeability end. However, the compressibility of water is quite independson of pressure in the pressure range of interest. ${ }^{10} \mathrm{We}$ do not expect the compressibility of water to deviate more than $2 \%$ from the value we used: its effect on error is therefore no more than $4^{\circ} \%$, A $10 \%$ increase in bulk compressibility of this rock (c.g., from 1.4 to $1.54 \times 10^{-4} \mathrm{MPa}^{-1}$ ) shifts the calculated curves by $10 \%$ toward the higher perneability end. We believe that the average stalic bulk compressibility 
TABLE 2. Input parameters to model studies.

\begin{tabular}{|c|c|c|}
\hline Paramoter & Value & Remarks \\
\hline $\begin{array}{l}\text { Upintrum reservoir volume } \\
\left(\mathrm{v}_{1}\right), \mathrm{cm}^{3}\end{array}$ & 594 and 546 & $\begin{array}{l}\text { Fig. } 2 \text { actual size } \approx \text { that used } \\
\text { in experiment }\end{array}$ \\
\hline $\begin{array}{l}\text { Downstream reservoir volume } \\
\left(V_{2}\right), \mathrm{cm}^{3}\end{array}$ & 9.25 and 545 & •• \\
\hline Sample cross-section area (A), $\mathrm{cm}^{2}$ & 5.07 & $"$ \\
\hline Sample length (L), cm & 3.81 & " \\
\hline Compressibility of water $(0), \mathrm{MPa}^{-1}$ & $4.2 \times 10^{-4}$ & Kennedy and Holser, Ref. 10 \\
\hline $\begin{array}{l}\text { Bulk compressibility of shale } \\
\left(\rho_{\text {eff }} \mathrm{MPa}^{-1}\right.\end{array}$ & $1.4 \times 10^{-4}$ & $\begin{array}{l}\text { Averaged static bulk compress } \\
\text { ibility of Eleana argillite from } \\
\text { depths up to } 367 \mathrm{~m} \text { at O.1MP. } \\
\text { (H.+M. Laboratory, Mercury, } \\
\text { Nevada, 1977, unpublished } \\
\text { data.) }\end{array}$ \\
\hline $\begin{array}{l}\text { Compressibility of solid matrix } \\
\text { of shale }\left(\beta_{\mathrm{g}}\right), \mathrm{MPa}^{-1}\end{array}$ & $2.66 \times 10^{-5}$ & $\begin{array}{l}\text { Compressibility of Devonian shale } \\
\text { st } 1.0 \mathrm{GPa}(\mathrm{Lin}, \text { unpublished } \\
\text { data, 1978) }\end{array}$ \\
\hline Viscosity of water $(\mu)$, Pa-s & $1.0 \times 10^{-3}$ & $\begin{array}{l}\text { Viscosity of water at } 20^{\circ} \mathrm{C} \text { and } \\
\text { 0.15 to } 100.0 \mathrm{MPa} \text { (Clark } \\
\text { Ref. 12) }\end{array}$ \\
\hline Porosity of shelc $(\phi)$ & 0.05 & $\begin{array}{l}\text { 0.5 of the avernged porosity of } \\
\text { Eleans shale (argillite) (Hudson } \\
\text { and Hoover, Ref. 1) }\end{array}$ \\
\hline Permeability $(k), \mathrm{cm}^{2}$ & $10^{-19}$ to $10^{-12}$ & Range of uxpected permeability \\
\hline
\end{tabular}

awe arbitrarily assume that the connected porosity of Eleana argillite is 0.5 of its total porosity. It is shown that in this case, the porosity does not affect the calculated pressure decay significantly.

of Eleana argillite from depths up to $367 \mathrm{~m}$ (Table 2) does not differ from that of Eleana argillite specimens we used by more th!an !o\%: the bulk compressibility of rock introduces an error of no more than $10 \%$, therefore. The probable error of viscosity is I to 2\%: the corresponding error in permeability is about the same. Varying the rock porosity from 0.05 10 0.1 or from 0.65 to 0.01 conIributes to the error of permeabilicy no more than 1 to $2 \%$. When we sum all these potential error factors, we estimate that the uncertainty of the permeability values is within $20 \%$ of the values reported in Table 3.

\section{RESULTS AND DISCUSSION}

Typical results from our argillite specimens are shown in Fig. 7 and summarized in Table 3. Figure 7 shows the permeabilities of specimens 6 and 7 (see Table I for their descriptions) as a function of effective pressure. These two specimens were taken from the same sample block; the effect of an induced fracture can be seen. In both specimens, the permeability, $k$, decreases with increasing effective pressure, $P_{E}$.
In Fig. 8, the data from Fig. 7 are roplotted in a $\log k$ vs $\log \mathrm{P}_{\mathrm{e}}$ scale. Clearly, permeability varies with negative power of effective pressure, i.e., $H \subset \mathrm{P}_{\mathrm{e}} \mathrm{N}$. Other specimens, except for 1 and 2 , show the same characteristics.

The same negative power relation holds in specimens 1 and 2 if we disregard the data at the effective pressure of $24.1 \mathrm{MPa}$. The possible decrease in bulk compressibility of rock at higher pressure 




FJG. 5. Comparison of corrected observation $(O)$ with calculated pressure necay curves (solid and dashed lines) for specimen 1. Permeability $(k)$ is determined to be $1.5102 .0 \times 10^{-17} \mathrm{~cm}^{2}$.

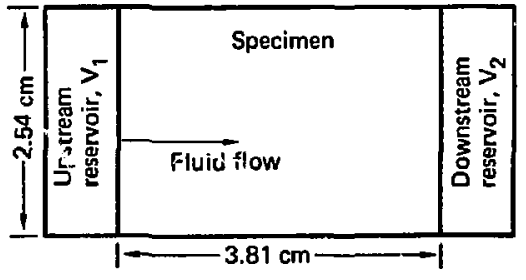

FIG. 6. Configuration of model study. $V_{1}$ and $V_{2}$ are the volumes of the upstream and downstream reservoirs, respcetively: fluid flows from $V_{1}$ to $V_{2}$. 


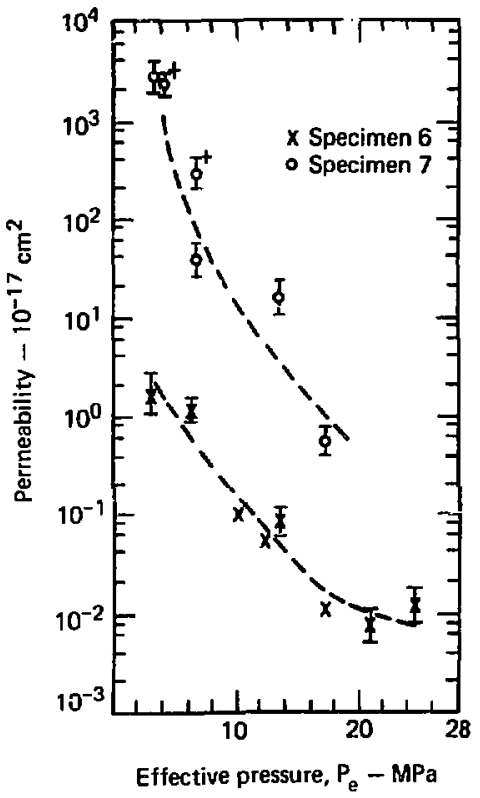

FIG. 7. Permeability of Eleang argillite as a function of effective pressure for specimeas 6 (intact) and 7 (fractured) from $361.2 \mathrm{~m}$ deep. The dashed lines are drawn to show the trend of the data. I data are the dafa from large-reservoir experiments.

may make the determined permeability too small. Although this may not fully explain the low permeability of these two specimens at 24.1 MPa effeetive pressure, we consider that the negative power is a good approximation for the data of these two specimens.

We calculated $N$ values by the least-squares method, as shown in Table 3. We can see from Table 3 that a fractured specimen has an $N$ value much greater than that of the corresponding intact specimen. This is because closing a fracture is $m$ trrlt easier than closing pores. Generally, intact argillite specimens hav: permeabilities at the lower end of

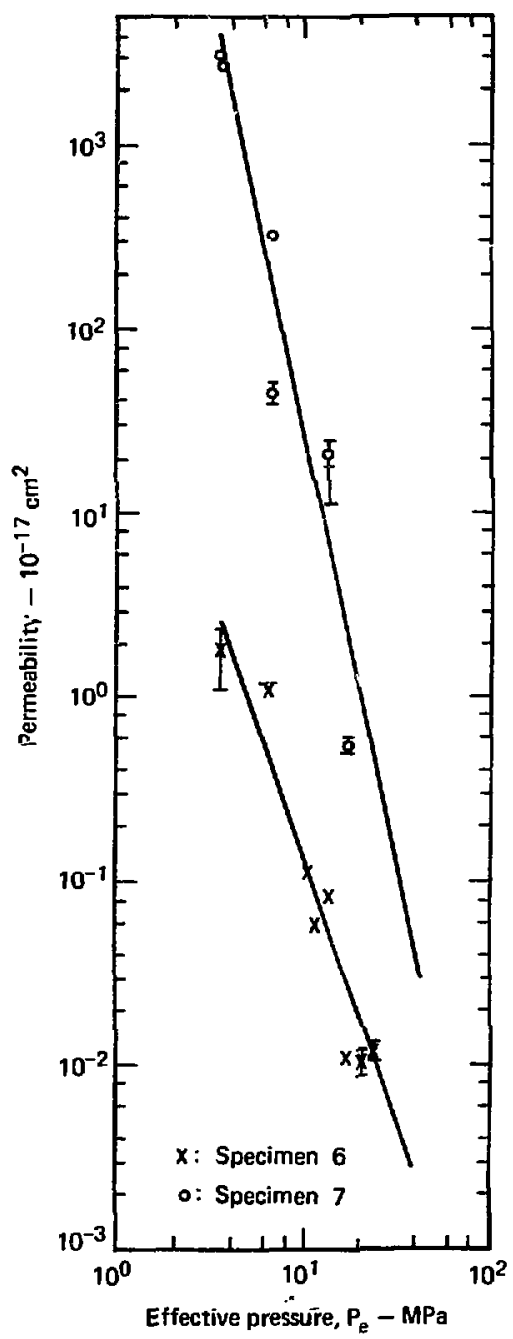

FIG. 8. Log-log plot of permeability of specimens 6 and $7 \mathrm{as}$ a function of effective pressure. The straight lines are fitted by the least-squares method. 
TABLE :. Permeability of Eleana argillite as a function of pressure and uffective pressure.

\begin{tabular}{|c|c|c|c|c|c|c|}
\hline $\begin{array}{l}\text { Specimen } \\
\text { No. }\end{array}$ & $\begin{array}{l}\text { Depth, } \\
\text { m }\end{array}$ & $\begin{array}{l}\text { Condition, } \\
\text { orientstion }^{2}\end{array}$ & $\begin{array}{c}\text { Confining } \\
\text { presoure, } \\
\text { MPs }\end{array}$ & $\begin{array}{c}\text { Effestive } \\
\text { pressure } \\
\text { Q }_{\mathrm{g}} \text { MPa }^{2}\end{array}$ & $\begin{array}{l}\text { Permeability } \\
\text { (k), } 10^{-17} \mathrm{~cm}^{2}\end{array}$ & $\left(k \propto \mathbf{P}_{\mathrm{e}} \mathrm{N}^{\mathrm{N}}\right.$ \\
\hline 1 & 102.1 & $\begin{array}{l}\text { Intact, } \\
\text { perallel }\end{array}$ & $\begin{array}{r}2.8 \\
2.8 \\
20.7 \\
48.3 \\
27.6 \\
2.8\end{array}$ & \begin{tabular}{r|}
1.1 \\
1.2 \\
10.1 \\
24.1 \\
13.1 \\
1.2
\end{tabular} & $\begin{array}{l}3.2 \sim 3.7 \\
1.5 \sim 2.0 \\
1.2 \\
0.3 \\
1.1 \\
2.2\end{array}$ & $\begin{array}{l}-0.28^{b} \\
\pm 0.09\end{array}$ \\
\hline 2 & $10 z .1$ & $\begin{array}{l}\text { Intact, } \\
\text { perpendicular }\end{array}$ & $\begin{array}{r}2.8 \\
2.8 \\
6.9 \\
20.7 \\
34.5 \\
48.3 \\
27.6\end{array}$ & $\begin{array}{r}1.3 \\
1.3 \\
3.5 \\
10.0 \\
16.8 \\
24.1 \\
13.7\end{array}$ & $\begin{array}{l}5.5 \\
8.0 \sim 10.0 \\
6.1 \sim 8.1 \\
1.2 \sim 2.2 \\
2.2 \\
(1.2 \sim 3.0) \times 10^{-1} \\
1.1\end{array}$ & $\begin{array}{l}-0.6^{b} \\
\$ 0.17\end{array}$ \\
\hline 3 & 102.1 & $\begin{array}{l}\text { Fractured, } \\
\text { perpendicules }\end{array}$ & $\begin{array}{r}2.8 \\
6.9 \\
20.7 \\
48.3 \\
48.3\end{array}$ & \begin{tabular}{r|}
1.2 \\
3.3 \\
10.3 \\
24.0 \\
23.7
\end{tabular} & $\begin{array}{l}8.5 \times 10^{4} \sim 1.1 \times 10^{5 c} \\
6.1 \times 10^{4} \sim 1.1 \times 10^{5 c} \\
(2.2 \sim 6.1\} \times 10^{1} \\
1.2 \sim 5.0 \\
8.1 \sim 11.0\end{array}$ & $\begin{array}{l}-3.6 \\
\pm 0.59\end{array}$ \\
\hline 4 & 358.4 & $\begin{array}{l}\text { Intach, } \\
\text { perpendiculy }\end{array}$ & $\begin{array}{r}6.9 \\
48.3\end{array}$ & $\begin{array}{r}3.2 \\
24.0\end{array}$ & $\begin{array}{l}0.8 \sim 3.1 \\
(1.1 \sim 2.2) \times 10^{-2}\end{array}$ & -2.0 \\
\hline 5 & 358.4 & $\begin{array}{l}\text { Fractured, } \\
\text { perpendicular }\end{array}$ & $\begin{array}{r}6.9 \\
6.9 \\
13.8 \\
13.8 \\
20.7 \\
34.5 \\
48.3\end{array}$ & $\begin{array}{r}3.4 \\
3.3 \\
6.8 \\
6.1 \\
6.5 \\
9.5 \\
16.9 \\
23.4\end{array}$ & $\begin{aligned} 8.1 & \times 10^{2} \sim 1.1 \times 10^{3} \\
(2.2 & \sim 3.7) \times 10^{35} \\
11.0 & \sim 22.0 \\
22.0 & \sim 35.0 \\
2.2 & \sim 4.2 \\
1.1 & \sim 2.0 \\
0.6 & \sim 1.0\end{aligned}$ & $\begin{array}{l}-5.7 \\
\pm 0.94\end{array}$ \\
\hline 6 & 361.2 & $\begin{array}{l}\text { Intach, } \\
\text { parallel }\end{array}$ & $\begin{array}{r}7.0 \\
13.8 \\
20.7 \\
27.6 \\
27.6 \\
34.5 \\
41.4 \\
48.3\end{array}$ & \begin{tabular}{r|}
3.5 \\
6.3 \\
10.3 \\
13.3 \\
12.1 \\
17.0 \\
20.7 \\
24.1
\end{tabular} & $\begin{array}{l}1.1 \sim 2.4 \\
1.1 \sim 1.2 \\
1.1 \times 10^{-1} \\
(8.1 \sim 9.0) \times 10^{-2} \\
6.0 \times 10^{-2} \\
1.1 \times 10^{-2} \\
9.1 \times 10^{-3} \sim 1.2 \times 10^{-2} \\
(1.1 \sim 1.3) \times 10^{-2}\end{array}$ & $\begin{array}{l}-3.0 \\
\pm 0.34\end{array}$ \\
\hline 7 & 361.2 & $\begin{array}{l}\text { Fractured, } \\
\text { parallel }\end{array}$ & $\begin{array}{r}7.0 \\
7.0 \\
13.8 \\
13.8 \\
13.8 \\
27.6 \\
34.5\end{array}$ & $\begin{array}{r}3.4 \\
3.5 \\
6.6 \\
6.6 \\
13.3 \\
17.1\end{array}$ & $\begin{array}{l}(2.4 \sim 4.0) \times 10^{3} \\
(2.4 \sim 3.0) \times 10^{3 c} \\
(2.4 \sim 4.0) \times 10^{2 c} \\
(4.0 \sim 5.0) \times 10^{1} \\
(1.1 \sim 2.5) \times 10^{1} \\
(5.0 \sim 6.0) \times 10^{-1}\end{array}$ & $\begin{array}{l}-4.7 \\
\pm 0.75\end{array}$ \\
\hline
\end{tabular}

"Condition is either intact or fractured. Orientation is either parallel or perpendicular to core axis.

bete at 24.1-MPa effective pressure are mot used to calculate N.

CData are obtained by using pui- of large reservoirs $\left(546\right.$ and $545 \mathrm{~cm}^{3}$ ). 
the range $\left(4 \times 10^{-4}\right.$ to $\left.10^{-17} \mathrm{~cm}^{2}\right)$ of shale 13 : these permeabilitics are itso to three orders of magnitude lower than the permeabilities published for Westerly granite 2 and Barre granite. ${ }^{\text {Is }}$

As shown in Fig. 7. a single through-going fracture in the specimen increases its permetibility significantly. The lower the effective pressure, the more pronounced the permeibility increase. Table 3 shows that this holds for all the specimens we studied. Tuble 3 and Fig. 7 ilso show that, at low pressure, the permeability of a fractured specimen is about four orders of magnitude greatter than that of the corresponding intact specimen: at higher pressures, the difference is one to tho orders of magnitude. This permeability differenee is probably due to permanent damage to the fractured surface during the fracture process. Also. beciase of the bedding of the specinen. the induced fracture is neither straight not snowth. The frateture surfice may not completely tose up at high pressure. It is possible that there are seatle elfects of fractured permersbility versus in silu fracture permeability. We do not take it into consideration in this laboratory study. The seile effect can be tvaluatled when the effect of fracture interaction on permeability is determined.

Our results indicate that the permeability of Eleana argillite is virtually constant along the axial and radial directions of the core axis (speximens 1 and 2, 4 and 6,5 and 7 . As mentioned in the rock description. the heddizg planes of these specimens dip from 30 to $60^{\circ}$ to the specinten axis. The isotropic character of permeability with respet to the hore-hoic axis maly be an elfect of hedding dip rather than in intrinsic propersy of the rock. To study the effect of bedding plane on permeability. we would have to test specimens either parallel or perpendicular to the hedding.

Our results also show that the deptb of origin of the specinen may affeet permeability. This is true for both intact and fractured specimens. The intact specimens from $102.1 \mathrm{~m}$ deep (specimens $I$ and 2) have a permeability aboct one to two orders of magnitude greater than that of intact specimens from 3.58 .4 and $361.2 \mathrm{~m}$ deep (specimens 4 and 6 ). This difference is more pronouneted at high pressure than at low prossure.

We have not attempled to study the lime dependence of permeability. When we removed specimenti from the apparatus at the ends of the experiments. we did observe that water left in the steel cap was contaminaled by clay mineral pasticles. This may be due to the disturbante of ti. specimen útring handling. It is not likely that mineral particles have been Iransported from the specimen. However, the importance of dissolving clay minerals in water on permeability variation over long periods is not yet clear.

Krans et al. ${ }^{4}$ reported that with effective pressure kept constant. the nerancability of jointed Barre granite decreased with increasing $P_{p} / P_{c}$ ratio. $W_{t}$ have not attempted to study this effect on the Fleanit argillite. As mentioned in the Introduction, 0.5 is a reatsonable $P_{p} / P_{c}$ ratio in a normal crustal condition.

\section{CONCLUSIONS}

From the viewpoint of water transport at room temperature, high-quartz Elcana argillite seems a viable alternate for repositories for highly radioactive waste for tither Westerly or Barre granite. Within the argillite itself, the permeability seems to decrease with increasing depth. We were not able to prepare the low-quartz specimen for permeahility measurement. The effect of losy-quartz content on the permeubility of Eleani argillite must be further studied. The effeets of tenperature, time, and anisotropy on permeability must also be thoroughly investigated.

Although one induced through-going fracture increatses the permeability significantly, the increase is not prohibitively great at high pressure. For a reasonably deep repository (500 zo 2000 i) deep). the presence of the fractures themselves would not necessarily exclude storing nuclear wastes stefely. A more exact analysis, relating the effect of fracture interaction to permeability, is needed. 


\section{ACKNOWLEDGMENTS}

D. Trinmer was indispensable for maintaining the pernıability apparatus. We thank R. L. Kranz. for making a preprint of his paper available. Discus- sion with H.C. Heard was helpful. The author thanks L. D. Ramspott. D. L. Hoover. and W. Ellis for their helpful comments.

\section{REFERENCES}

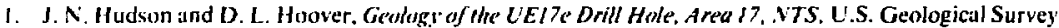
Repl., in press.

2. M. K. Hubberl and W. W. Rubey, "Mechanics of fluid-filled porous solids and its application to overthrust faulting," Geol. Soc. Am. Bull., 70, 115 (1959).

3. W. F. Brace, J. B. Walsh, and W. T. Frangos, "Permeability of Granite Under High Pressure," $J$. Geophls. Res. 73, 2225 (1968).

4. W. I.in. Cimmpressible Fluid Flow Throngh Rocks of Variable Permeability, Lawrence Livermore L.aboralory. Livermore. Calif., UCRL-52304 (1977).

5. H. C. Heilrd and A. G. Duba, Capabilines for Measuring Physicochemical Properit's at High Pressure. L.al rence i.ivermire Laboratory, Livermore, Calif., UCRL-52420 (1978).

6. J. F. I.akner. A Hew Apparatus for Permeabiliny Measurements Under Lisho-Siaric Comatitions and Resulss ail Drep Fractured and High Explosive Fractured Oil Shale, Lawrence Livermore Laboratory, Livermore. atif.. UCRL_-50562 (1968),

7. R. Quong and V. J. La Guardia, Permeability of Pictured ('liffs Sandstone: Gashuggl Preshot and Postwhet Measurements, Lawrence Livermore Laboratory, Livermore, Calif., UCRL-5C946 (1970).

8. R. Quong and J. Baker. Computer-Comtolled Apparatus for Permeability Measuremems at Confining Presuires up (1" $10^{2}$ Pascal $1 / 0^{3}$ bar), Lawrence Livermore Laboratory, Livermore, Calif., UCID-30073 (1974).

9. A. L. Eduards, TRUMP: A Computer Program for Transient and Steady-State Temperature Distribution.s in Multidimensirnal Syxtems, Lawrence Livermore Laboratory, Liverme-e.. Calif.. UCRL-14754, Rev. 3 (1972).

10. G. C. Kennedy and W.T. Holser, "Pressure-Volume-Temperature and Phase Relations of Wuler and Carbon Dioxide," in Handhook of Physical Consıants, S. P. Clark, Jr., Ed. (Geological Society of America, Memoir 97, 1966), p. 371.

11. 1- Birch, "Compressibility: Elastic Constants," in Handbook of Physical Constants. S. P. Clark, Jr.. Ed. (Geological Society of America, Memoir 97, 1966). p. 167.

12. S. P. Clark, Jr., "Viscosity of Water and Steam," in Handbook of Phisical Constants, S. P. Clurk. Jr., Ed. (Geological Socicty of America, Memoir 97, 1966), p. 300.

13. M. Gondouin and C. Scala, "Streaming Potential and the SP Log." J. Petrol. Terth. 10 (AINiE Tech. Paper 8023). 170 (1958).

14. R. L. Kranz. A. D. Frankel, T. E. Engelder, and C. H. Schalz. The Permeahility of Whole and Jointed Barre Granile (submitted to Iht. J. Rock Mech. Min. Sci)... 